An ESRC Research Group

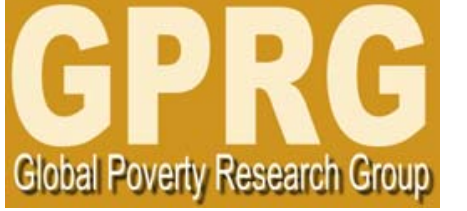

\title{
Reclaiming development? NGOs and the challenge of alternatives
}

\author{
GPRG-WPS-043
}

Diana Mitlin, Sam Hickey and Anthony Bebbington

\section{Global Poverty Research Group}

Website: http://www.gprg.org/

The support of the Economic and Social Research Council (ESRC) is gratefully acknowledged. The work was part of the programme of the ESRC Global Poverty Research Group. 


\title{
Reclaiming development? NGOs and the challenge of alternatives ${ }^{1}$
}

\author{
Diana Mitlin, Sam Hickey and Anthony Bebbington \\ Global Poverty Research Group; and \\ Institute for Development Policy and Management \\ School of Environment and Development \\ University of Manchester \\ Diana.mitlin@manchester.ac.uk \\ Sam.Hickey@manchester.ac.uk \\ Tony.Bebbington@manchester.ac.uk
}

\begin{abstract}
In 1987, World Development published a supplement entitled 'Development Alternatives: the Challenge of NGOs'. Although this challenge now seems far more complicated, this paper suggests one way of giving meaning (and possibility) back to the juxtaposition of 'development alternative' and NGOs. Where NGOs have pursued radical rather than merely reformist alternatives, this has usually been in conjunction with political programmes of social movements or developmentalist states. NGOs need to rethink the notion of development alternatives in terms of the politics and political economy of social change, a rethinking that will help define the contours for a theory of NGOs.
\end{abstract}

Key words: development alternatives, development theory, non-governmental organisations, civil society.

(C) Diana Mitlin, Sam Hickey and Anthony Bebbington 2006 


\section{Introduction}

In 1987, World Development published a supplement entitled 'Development Alternatives: the Challenge of NGOs' (Drabek, 1987). Twenty years of development studies later, everything seems more complicated: it has become defensible to claim that 'there is no alternative,' that the term NGOs has no analytical or even descriptive value, that development is a form of governmentality rather than a project of emancipation, and that it is far more important to ask how the term is used to serve particular (increasingly global) interests rather than to ask what it means. The supplement's title, once eyecatching, now seems to fall apart under the weight of the apparent meaninglessness or impossibility of its terms. This paper attempts to restate this reflection on the relationship between NGOs and development alternatives. It does so through four steps. It begins with a reflection on the concept of 'development,' one that stakes out a terrain on which the term can be defended as having both analytical and normative force. This then lays the base for discussing possible meanings of 'alternative' development. Second, it suggests a conceptualization of nongovernmental organization that gives the term more meaning at the same time as linking it to the concept of development through a reflection on the meaning of civil society. Third, it places a discussion of NGOs and development in terms of relationships and flows that are as much global as local in their reach, and link processes and actors at different sites across space and time. Fourth it offers a review of both historical and contemporary experiences of the roles of NGOs in development and the pursuit of something called 'alternatives.' 
Integral to reflections on NGOs for two decades, thinking about NGOs as alternatives has gone somewhat missing of late. The NGO literature has been voluminous since the 1980s, termed by some the 'NGO decade' (Bratton 1989), with these 'new' actors frequently lauded as the institutional 'alternative' to existing development approaches. Critical voices at this point were largely muted, confined to expressing concern that NGOs might be an externally imposed phenomenon that, far from being alternative heralded a new wave of imperialism (Tandon 1991). Apparently inclined to offer the benefit of the doubt, much of the literature focused on locating the importance of NGOs as a key plank within the emerging 'New Policy Agenda', including a new role at the vanguard of donor agendas on 'civil society' and 'democratisation' (Robinson 1995). The diversification and multiplication of $\mathrm{NGO}$ activities and their move to the mainstream came under close critical scrutiny, both from supporters and sceptics of the NGO phenomenon. 'Internal' debates looked both ways. On the one hand were discussions of how to scale-up NGO activities (Edwards and Hulme 1992), how to run NGOs more successfully and ensure their sustainability as organisations (e.g. Fowler 1997, 2000a, Lewis 2001) and how NGOs might better manage their relationships (Groves and Hinton 2004). On the other, commentators feared that closeness to the 'mainstream' undermined their 'comparative advantage' as agents of alternative development, with particular attention falling on problems of standardisation and upwards accountability (Edwards and Hulme 1996, Wallace et al 1997), on the effectiveness of NGOs in reaching the poorest (Edwards and Hulme 1995, Riddell and Robinson 1995, Vivian 1994), and an apparent increased tendency to employ 'radical' methods of empowerment such as participation as technical means rather than political ends (Lane 1995). The apparently limited success of 
NGOs as agents of democratisation came under critique from within (e.g. Fowler 1993) and without (e.g. Marcussen 1996, Stewart 1997, Mercer 2002), while the simmering debate over NGOs as an externally driven phenomenon that threatened the development of 'indigenous civil society' and distracted from more political organisations re-emerged (e.g. Hashemi 1995, Mamdani 1993). Such concerns seemed to feed a period of millennial angst within the sector, with growing calls for 'northern' NGOs in particular to devise new roles and rationales for themselves (Lewis and Wallace 2000) or risk becoming obsolete (van Rooy 2000). NGOs were advised to reach beyond the aid system for alternative forms of funding (Aldaba et al 2000, Fowler 2000b) while also lobbying for a fundamental restructuring of the international aid system itself (Edwards 1999).

However, and while the academic output on NGOs remains more diverse than has been fully reviewed here, what has perhaps been most remarkable of late is the extent to which these critical concerns have been allowed to pass by with very little evidence that they have been seriously addressed. We are arguably no clearer now concerning questions of effectiveness, accountability and successful routes to scaling-up than we were when these questions were raised over a decade ago, let alone concerning the wider challenge of what being 'alternative' means at this juncture (Tandon 2001). And while some NGOs have undergone profound institutional changes (e.g. ActionAid's relocation to South Africa), a sense of complacency concerning these and other key challenges appears to have replaced the earlier sense of angst. It is perhaps a frustration with this as much as anything that encourages us to ask again whether and how NGOs might re-engage with their founding project of offering genuine 'alternatives'. 
With this background and the above four steps in mind, the paper elaborates a framework for discussing the links between development and NGOs. It then uses the framework to review NGO modern history, since the 1960s. In the light of that review, the final section suggests possible futures in the relationships between NGOs and alternatives. In this sense, the paper is both analytical and normative for, as will become clear, we are specially interested in particular alternatives - those reworking state-society relationships towards more radical, socially inclusive forms of citizenship (Hickey and Mohan, 2005), and reworking economic relationships such that markets have more potential to become vehicles of social justice. ${ }^{2}$

\section{A framework for thinking about development alternatives}

It is important to think about the role of NGOs in development in relation to at least three dimensions. The first concerns examining development both as both an underlying process of social change and as a targeted intervention; the second concerns the tripartite division between the three key institutional arenas of state, civil society and market; and the third relates to the relationships between localizing and globalizing tendencies in defining what NGOs do and are.

\section{D(d)evelopment/A(a)lternative(s)}


In their history of 'doctrines of development,' Cowen and Shenton (1996; 1998) distinguish between two meanings of the term 'development' that have been consistently confused: 'development as an immanent and unintentional process as in, for example, the ‘development of capitalism' and development as an intentional activity’ (1998: 50). Others have used this distinction to frame thinking about development theory and practices (Bebbington, 2000; Hart, 2001; Hickey and Mohan, 2005), though Hart (2001) amends it slightly to talk of 'little d' and 'big D' d/Development. The former involves the 'geographically uneven, profoundly contradictory' set of processes underlying capitalist developments, while the latter refers to the 'project of intervention in the 'third world' that emerged in a context of decolonization and the cold war' (ibid: 650). While these frameworks differ slightly in their details they each insist on distinguishing between notions of intervention and of political economic, structural change when thinking about development, without losing the sense that there are clear, if non-deterministic, relationships between these two faces of development (Bebbington, 2003). We can locate NGOs in this simple framework, in the sense that they are - whether as project implementers, knowledge generators or political activists - all involved in intervention, but are also part of the societies and political economies in which they operate: they are part of the little $d$ development at the same time as they try, through big $D$ Development, to intervene in and modify the nature and/or effects of the broader processes of this little $d$ development. NGOs are, then, both endogenous to development (understood in its systemic sense) while often being viewed (and viewing themselves) as exogenous to it when they engage in their interventions. 
Alternatives can also be thought of in relation to this distinction. Much discussion of alternatives has been in relation to Big D Development - NGOs have been seen as sources of alternative ways of arranging microfinance, project planning, service delivery and so on: i.e. alternative ways of intervening. These are reformist notions of alternatives - different ways of intervening to ensure greater participation, people-centredness etc. However, alternatives can also be conceived in relation to the underlying processes of capitalist (or socialist) development. Here the emphasis is on alternative ways of organizing the economy, politics and social relationships in a society. When an Evo Morales in Bolivia speaks of a commitment (real or not) to finding distinct, non-neoliberal ways of organizing the economy, or when Ecuador's indigenous movement demands different ways of organizing and legislating around ethnic relationships and state formation this is the type of alternative invoked. In some sense, the distinction here is similar to that made by Escobar (1995) between 'development alternatives' and 'alternatives to development' - the former seen as exercises in reform having little effect on the underlying role of development in ordering and governing society, the latter as exercises more likely to transform society and enhance human fulfillment. The distinction, then, is between a partial, reformist, intervention specific alternative, and a structure changing, radical, systemic alternative

\section{Civil society/alternatives}

The second element of our framework links these distinctions to a reflection on state, market and civil society. The tripartite division between these spheres is often used to 
understand and locate NGOs as civil society actors (Bebbington 1997; Fisher, 1998; Hyden, 1997; Fowler 2000b). Yet many of these renderings are problematic. First, the treatment of civil society is often excessively normative rather than analytical: it is seen as a source of 'good,' distinct from a 'bad' imputed to the state and market. The roots of this approach run deep: for some, the essential role for civil society has long been to preserve a central place for a social logic to define the life-spaces of citizens in the face of the hegemonic advances of the state (e.g. Habermas), while for others it plays much the same role vis-à-vis unfettered market forces (e.g. Polanyi; see Burawoy 2003). ${ }^{3}$ Such approaches understate the potential role of the state in fostering progressive change while also downplaying the extent to which civil society of activity for racist organizations, neo-liberal research NGOs or other organizations that most of these authors would not consider benign (Stone, 2000; Hearn, 2001; Lewis, 2002). ${ }^{4}$

Second, even if the need to understand the three spheres in relation to each other is often recognized, the relative fluidity of the boundaries among them as people move back and forth between NGOs, government and occasionally business has received less attention. Such movements have further problematised the understanding of NGOs as being an integral part of civil society, something already called into question by those who argue that NGOs can be more accurately seen as corporate entities acting according to the logic of the market-place (Stewart 1997, Uphoff 1995). Perhaps more important, though, is that the 'civil society' in which NGOs have been located in these discussions has rarely been considered with much historical depth. Yet, some exceptions notwithstanding (see Lewis, 2005), NGOs are a relatively recent organizational form whose emergence can 
only be understood in terms of their relationships to far more deeply seated social arrangements linked, for instance, to religious institutions, political movements, government and transnational networks of various kinds (Bebbington, 2004). That is, NGOs - why they exist, what they do, what they say, who they relate to - can only be understood in terms of their relationship to these more constitutive actors in society, as well as in terms of the relationships among these constitutive actors, and between them, state and market. This does not mean that NGOs are merely instruments of these actors (though they may be) - it does mean that they are not constitutive, and are certainly not the most important actor in civil society.

Civil society - and the place of NGOs within it - must therefore be treated carefully, historically, conceptually and above all relationally. It can be argued that within development studies civil society has been predominantly understood in two main ways, at each of two main levels (Bebbington and Hickey, 2006). At the level of ideology and theory, the notion of civil society has flourished most fruitfully within either the neoliberal school of thought that advocates a reduced role for the state or a postmarxist/post-structural approach that emphasises the transformative potential of social movements within civil society. At the conceptual level, civil society is usually treated in terms of associations (so-called civil society organizations), or as an arena within which ideas about the ordering of social life are debated and contested. In this paper we work from a broadly Gramscian understanding of civil society as constituting an arena in which hegemonic ideas are both established and contested. These contestations, the hegemonies which emerge and the roles (if any) that distinct NGOs play in this must in 
turn be understood in terms of the relationships and struggles for power among the constitutive actors of society.

These contestations over hegemony can also be related to our framing of 'alternatives.' Thus, one can imagine certain alternatives in the domain of Big D Development, that challenge ideas that are dominant, but not foundational. For instance, dominant ideas about how health care or financial service provision ought to be organized, might be contested and challenged by actors proposing and promoting distinct models of provision. Such alternatives, important though they may be in welfare terms, do not challenge the more basic arrangements that order society. Conversely, one can also imagine hegemonic ideas that are far more foundational - for instance, in the present moment, neo-liberal ideas regarding how society and market ought to be governed; or ideas about property rights. These ideas can also be contested with alternatives in the domain of little 'd' development.'

\section{Glocal NGOs}

While concepts of global civil society may have their difficulties, there can be little doubt that, as the most potent force within late modernity, globalisation has (re)shaped NGOs and how they must be thought of. One effect has been that (at least some) NGOs have increasingly become a transnational community, itself overlapping with other transnational networks and institutions (Townsend 1999). These linkages and networks disperse new forms of development discourse and modes of governance as well as 
resources throughout the global south; and some Southern NGOs have (albeit to a lesser extent) begun to gain their own footholds in the North with their outposts in Brussels, Washington and elsewhere. Yet these transnationalizing tendencies have also excluded certain actors and groups for whom engagement in such processes is harder. Thus these moves to scale have simultaneously increased the distance between parts of the sector and led to the emergence of international civil society elites who come to dominate the discourses and flows that are channeled through this transnational community. This raises serious questions as to whose alternatives gain greater visibility in these processes. 5

This transnationalizing of intervention (big D) reflects structural transformations in the workings of national and international capitalisms and the nature of organizations in capitalist society. These changes make it important for any alternative project (in a Gramscian sense) to work simultaneously at different points within these chains of intervention. They have also involved the increased channeling of (national and multilateral) state controlled resources through NGOs - a channeling in which resources become bundled with particular rules and ideas regarding how they must be governed, and contribute to the governing of others. This bundling has meant NGOs become increasingly subject to the dominant ideas and rules that travel with development finance - in particular ideas related to neoliberalism and security. This has made life difficult for many northern NGOs, who in turn pass on these difficulties to their partners. Indeed, as Northern NGOs talk of partnership and decentering, their means of exerting influence remain powerful. For these reasons, other Northern NGOs continue firm in the 
determination not to accept (largely government) resources that come bundled with such rules.

It is a short step to move from such observations to suggest that NGOs are becoming vehicles of neo-liberal governmentality (e.g. Townsend et al 2002), disciplining local organizations and populations in much the same way as development programmes have done in the past (Escobar, 1995; see Duffield, 2001 for hints of such a conclusion). Such a reading, however, understates the extent to which such pressures are resisted by some NGOs (Townsend et al., 2004), and the extent to which an NGO's ability to sustain a broader funding base can be a tool that helps it negotiate and rework some of these pressures. It also understates the potential ability of NGOs to mobilize the broader networks and institutions within which they are embedded as a means of muting such disciplining effects. These networks can provide other resources and relationships of power on which the organization can draw - be these based in the Jesuit community, transnational corporate actors (who appear on a number of NGO boards), or underlying networks of power within the movements for Social Democracy, to name a few. Nor are transnational NGO networks necessarily characterized by uneven North-South relations, as the more horizontal experience of Slum Dwellers International shows (Patel and Mitlin 2002). Finally, the simple governmentalizing reading perhaps also overstates the extent to which it is possible to talk of neo-liberalism in coherent and singular ways while some critical commentators talk of neo-liberalisms (in the plural) with at best some 'family resemblances' (Peck, 2004). 
Nonetheless, even if such resistances, reworkings and slippages might occur, they do so for conjunctural rather than necessary reasons and so it remains essential to understand NGOs - as well as states, markets and civil societies - in the context of these transnational relations and flows. As noted earlier, NGOs are part of while trying to be apart from the political economy - and the workings of this political economy are transnational in nature and global in reach. As such, we re-iterate the point that, for NGOs to regain a sense of being and offering alternatives, they need to be (re)consider themselves in relation to struggles over 'little $d$ ' development as a foundational, underlying and increasingly globalised form of social change - and not simply in relation to the state or market, or to doing development differently.

\section{NGOs as development alternatives: the road less traveled}

While the growth of NGOs has been well reviewed (Clark, 1991; Edwards and Hulme, 1996; Hulme, 1994; Fisher, 1998, 1993), Lewis (2005) argues that much analysis of NGOs has lacked theoretical acuity. This section therefore approaches this modern history through the lens of our organizing framework and in a way that helps speak to our overall concern for the place of NGOs in fashioning alternative forms of development. We divide this abridged history into four main phases, without suggesting any precise dates for each phase. ${ }^{6}$

\section{An abridged history of $\mathrm{NGO}$ a/Alternatives}


The first period is characterized by the quite long history of a limited number of small agencies seeking to respond to the needs of groups of people perceived as poor and who received little external professional support. These largely issue based organizations combined both philanthropic action and advocacy - as for instance in the case of the abolition of slavery and promotion of peace (Charnovitz, 1997, cited in Lewis, 2005). Most were northern based, but some had a southern presence, and they were generally embedded both in broader movements (e.g. against slavery) and networks that mobilized voluntary contributions. They were often linked to other organizations providing them with an institutional base and funding, and frequently linked to wider religious institutions and philanthropists. There were also clear interactions with the state around legal reform as well as with the market which generated most of the resources then transferred through foundations (a model that of course continues through to today, on a far more massive scale). ${ }^{7}$ From the North, at least some such interventions were linked into conceptions that were a legacy of colonialism such as volunteer programmes sending experts to 'under-capacitated' countries or organisations that derived from missionary interventions. While some interventions were of organizations whose mission and/or staff recognised the need for structural reform (Hirschman, 1984), only rarely was such work alternative in any systemic sense, or in the sense that it sought to change the balance of hegemonic ideas, be these about the organization of society or the provision of services.

Such organizations continued their work (some closed down, others were created) during the 1960s and 1970s (broadly our second phase). Although they remained relatively 
small scale, in some countries and some sectors this period marked early stages in NGO growth. Reflecting the geopolitical moment, the sector became increasingly critical, engaging more fully with the notion that it was imperative that NGOs elaborate and contribute to alternative arrangements among state, market and civil society (generally on a national rather than a transnational scale), and alternatives both within, and to, capitalism. In this period little $d$ development was increasingly scrutinized, reflecting the intersection between these NGOs and political struggles around independence and various socialisms, as well as between these political projects and intellectual debates around dependency, structuralist and broadly Marxian interpretations of the development process (Lehmann, 1990; Watts, 2001). 'Alternative development' itself emerged most strongly in this era (e.g. Nerfin 1977), albeit in the form that tended to simply invert mainstream forms of 'big-D' Development rather than offering alternative forms of 'little-d' development.

Such debates - and the student, political and other protest movements to which they were linked - happened both North and South, and one artifact of this in the North was the creation of, and/or growing penetration of existing NGOs, by people steeped in such debates (Hulme 1994). It was also - not uncoincidently - a period in which these nongovernmental vehicles for 'alternative' development discourses developed increasing links to the more formal worlds of development finance and political party funding as evidenced by the growth of co-financing programmes and the Stiftung phenomenon (OECD, 1988; Bebbington, 2004). The sector, though small, was increasingly conscious of itself and of the need to build collaborations with other nongovernmental actors, 
particularly across North-South boundaries. Numerous forces - awareness of the need for local institutional development, reduction in the formal colonial presence, and the contradictions inherent in the Northern NGO model - resulted in a switch from operational to funding roles for Northern NGOs and the growth of a Southern NGO sector.

This was a period in which a growing number of NGOs, in particular those embedded in institutions and networks of political and religious lefts, consciously sought to shift statemarket-civil society arrangements through government policy. ${ }^{8} \quad$ Perhaps the dominant conception was one in which NGOs developed new strategies and then lobbied for their incorporation into government either directly or - particularly under oppressive states where different rules applied - indirectly, through fostering social mobilization. Indeed, this was a period in which very many NGOs negotiated space within and alongside other political and social movements. This process was one of collaboration among actors who recognized the benefits of the joint existence of movements, supportive institutions and NGOs within the struggle against hegemonic and repressive structures manifested through the state (e.g. Philippines, South Africa, El Salvador). On the part of such NGOs, there was a recognised need for political change, whilst on the part of (some of) the political movements the NGO contribution was recognized as important -as a means of accessing a range of resources. Often, the relationships between these actors ran far more deeply with NGO staff being simultaneously active in political parties and movements (such as, for example, PlanAct and ANC in South Africa, or PRISMA and FMLN in El Salvador). 
These were also the periods when European co-financing resources were (often deliberately) given without many questions, in order to channel resources to oppositional movements via NGOs without any explicit, traceable government knowledge. These were also the years where other governments and conservative forces - most notably the US - used a not dissimilar tactic to support elements of the hegemonic forces and ideas against which these NGOs and political movements were struggling. Some of these conservative resources were also channeled through NGOs, and continue to be so. Indeed, both in this phase as well as in later arguments over neo-liberalism, the role of NGOs both in strategies of contesting hegemony as well as in other strategies aimed at consolidating it, was more than apparent. Such phenomena led to many manifestations such as the co-existence of competing NGO networks, some conservatively funded, others more radically funded- that symptomized the extent to which the nongovernmental sector was one of the more important terrains in which civil society was being contested (c.f. MacDonald, 1994; Howell and Pearce, 2001) and in which the alternatives at stake were systemic as much as sectoral.

Our third phase is defined by the growth in recognition for NGOs and their work and the increasing interest in funding such activities, often in relationships with the state and development agencies. This is the period of the NGO 'boom,' a boom that can only be understood in terms of its own relationship to transformations in the structures of capitalisms North, South and globally in this period - a reminder that NGOs have to be understood in terms of the political economies in which they exist. We would draw 
attention to three particular shifts in the broader relationships among state, market and civil society as being important in this regard: macro-economic instability and crisis in a significant number of countries; political democratization, from both dictatorships and 'enlightened authoritarian' regimes towards more formally liberal democracies; and a shift in dominant development discourse, with concepts and practices such as 'civil society' and participation assuming great (discursive) centrality.

The 1980s were dominated by structural adjustment programmes and the attendant increase in poverty and reduction in the role of governments in (their already weak capacity for) managing markets and public services. Adjustment led to a series of demands - across the political spectrum - for NGO intervention as programme implementers, knowledge generators and activists, depending somewhat on where (politically) the demands originated. Those interests generally supportive of structural adjustment needed NGOs to help deal with the limitations of a strategy that was generating political protest that challenged the very viability of the reform process. The family of social emergency, investment and other compensation and social protection funds that were created in order to deal with these inadequacies were (consistent with the model) increasingly implemented by non-state agencies including NGOs. This demand and the increased opportunities - for NGO intervention derived from a particular vision in which the place of the state in little d development had been reduced, while that of market and civil society had grown. Yet the viability of these larger reforms required reformist alternatives at the margin of the model that would build in a measure of social redistribution to market-based policies and so help sustain reform during (what was 
perceived as) a transitional period in which the negative effects of adjustment were an internal contradiction. The model itself was not in question and certainly this source of support for NGOs did not help them contest it, even if they wished to. ${ }^{9}$

Those who opposed structural adjustment looked to NGOs to document the scale of suffering caused and to demonstrate the feasibility of coherent alternatives that also took account of the previous failure of government to deliver to the poor. Arguably NGOs were far more effective at the documentation of failure than the elaboration of alternatives - though it can be reasonably argued that the very context of adjustment made it that much more difficult to identify alternatives. Much was expected of NGOs in this period but in reality expectations were unfair and unrealistic. While there was some 'discourse space' and there were financial resources for collaborative projects, there was little to no space to pursue large-scale or system-questioning alternative projects. Again the broader context of little $\mathrm{d}$ development constrained the possibility that big D interventions - through research, activism, advocacy or experimentation - would achieve very much.

Yet the 1980 s were not entirely lost to systemic alternatives. Some countries witnessed a resurgence of new social movements (Slater, 1985; Alvarez et al., 1998; Ballard et al., 2005). Even if such patterns of resurgence might be viewed by skeptics as exceptions that proved the rule, they suggested other pathways through which alternatives might be built, more slowly and systematically, around concepts of citizenship, identity and organization (c.f. Escobar, 2001, 1995). These alternatives, in some countries, 
challenged dominant thinking on the social, if not the economic, order. These were, though, processes led by social movements, and if NGOs contributed, it was as part of these movements (as social movement organizations: McCarthy and Zald, 1977). That is, the possibility that they contributed to more systemic alternatives hinged largely on their being linked to broader processes of social organization.

Adjustment was also accompanied by political democratization, partly as the political correlate of neoliberalism, ${ }^{10}$ but also as a response to long years of organizing within civil society in which NGOs had played a role along with other actors. Ironically, this democratization brought further complications to NGOs (e.g. Clarke 1998 on South Asia, Bratton 1989 on Africa; Alvarez et al., 1998 on Latin America). The task of shifting from a position of contesting authoritarian governments to engaging with and promoting new, and often partial democracies, has been a defining challenge for NGOs since the mid-late 1980s in parts of Latin America and SE Asia, and from the early-mid 1990s in subSaharan Africa. Once newly democratic state institutions took up alternatives for which NGOs had pushed, NGOs were left with the uncertainty of what to do next other than help the state make a success of these new orthodoxies. Indeed, many NGO staff and movement activists have moved into government precisely to try and help foster such success - a process sometimes viewed as co-optation rather than success. Examples here range from NGO leaders gaining seats in national cabinets (e.g. the Philippines) and ministries (e.g. Chile), the women's movement moving into parliament in South Africa and Uganda (Goetz 2003, Geisler 2000), and pervasive and important shifts of NGO activists into local government. 
If democratization marked a success in delivering a systemic alternative in which NGOs could claim some role, the alternative was incomplete and complex in two senses. First, while relationships between state and civil society were transformed, those between state and market were largely unaffected, and those between market and civil society appeared to further commodify of social relations. Second, the growing closeness of NGOs to the Big D interventions molded by national and multilateral organizations led to the concern that NGOs had become 'too close for comfort' in Edwards and Hulme's (1996) term to a range of other actors in a way that compromised their innovativeness, autonomy, legitimacy, accountability and ability to continue elaborating alternatives. Others noted the narrowing field of interventions considered by NGOs and the adoption of ways of working that restricted their effectiveness (Wallace et al 1997), while Tandon (2001) worried that the political economy of aid restricted the building of horizontal relationships with other actors in civil and political society. Many authors and practitioners worried that becoming public service contractors (Robinson, 1997) was tying NGOs into mainstream approaches more than ever before.

Authors from different regions argued that it had become increasingly difficult for NGOs to offer little 'd' development alternatives (Aldaba et al., 2000), though these general concerns were mirrored in regionally specific reflections. The new geopolitical economy of nongovernmental aid left Latin American NGOs financially strapped, leading many to engage in these dominant projects in order to access resources, even knowing that this would compromise their mission and coherence as organizations (Bebbington, 1997). In 
Bangladesh, politically radical NGOs, such as Proshika and GSS, shifted the balance of their work, reducing conscientisation and popular mobilization activities and increasing large-scale micro-credit. Arguably the shift from being NGO to micro-finance agency represented a significant diminution in ambition by at least some NGOs (Dichter 1996). In several parts of Africa, NGOs were mobilizing to fight against legislation from governments that often viewed the sector with suspicion (Gary 1996, Gariyo 1995, Ndegwa 1996), often without significant others in 'civil society' to draw strength from. Indeed, it has been argued that, many local NGOs, particularly in Africa, simply lacked the 'power' to define either their own futures or development paths for poor people (Michael 2004), alternative or otherwise.

\section{Recent and contemporary alternatives}

Not all shared a sense of pending institutional doom - some NGO leaders questioned the tendency of Northern commentators to impute crises where they didn't exist. Indeed, a decade later it seems that stories of their 'coming' demise had been greatly exaggerated. Yet, NGOs have hardly become more robust, and pressures over the last decade - our fourth period - present an additional set of health threats some more obvious, others less intuitive. We draw attention to three apparent trends in this period that impinge directly on NGOs and the scope for building either systemic or reformist alternatives: the continued deepening of the democratization-neo-liberalization agenda; the hegemony of a poverty agenda in international aid; and the relatively more recent, hugely pernicious, security agenda itself coupled in strange ways with the poverty agenda. 
With the creation of the WTO, the neo-liberalization of social democracy, and the increasing tendency towards military enforcement of liberal democratic process, the joint project of liberal democracy and free trade seems to have become increasingly clear and consolidated in this latter period making it ever more difficult for NGOs or other actors to think or act outside of this neo-liberal box. ${ }^{11}$ This is particularly so because the box has incorporated much core NGO terminology around democracy, rights, empowerment, participation, poverty and livelihood. At the same time there are incentives to engage with - indeed, become part of - hegemonic forms of little d development, as these begin to look more attractive. Market-based development has been seen to move down to poorer groups with the extension of micro-finance services. This is proof, for some, of the potential of the market to be inclusive and to create opportunities for the poor. The shift towards democratization has been accompanied by the scaling up of the participatory turn, the high-point of which has been the poverty reduction strategy papers phenomenon. This has offered some NGOs unprecedented levels of access to at least part of the policy process but also brings challenges, particularly concerning the capacity and legitimacy of NGOs to act as pseudo-democratic representatives of 'the poor', and the risks of being associated with processes that may in themselves undermine broader democratic norms. There are real dangers that the participatory turn can and does obscure more legitimate and effective forms of democratic representation (Brown 2004; Cooke and Kothari, 2001; Hickey and Bracking, 2005). Some NGOs, keen to secure their seat at the new range of tables open to them within 'inclusive' policy processes, have been 
perhaps too keen to grasp and extend these channels, without thinking through the longer term problems what this raises for public accountability in developing country contexts.

Closely related has been the new-found hegemony for 'poverty reduction' within international development. Notwithstanding efforts to use poverty to discuss politics (Green and Hulme, 2005), the tendency is still toward a narrow definition where reducing income poverty remains the central goal - reflected in its position as the first and ultimate MDG. The (very considerable) resources flowing from bilateral and some multilateral agencies to NGOs are increasingly bundled with this poverty reduction agenda, placing increasing demands on these NGOs to deliver measurable achievements in poverty reduction. While it is hard to contest the worthiness of such goals, this emphasis has the potential not only to rein in but also depoliticize the range of strategies open to NGOs in promoting development. There is at least some evidence that the demands for poverty reduction are affecting: the types of social organizations that NGOs work with (with shifts to production and credit groups and away from representative social movements); the types of intervention such NGOs engage in, with a tendency to seek poverty reduction impacts rather than redistributive effects; the regions of the world for which NGOs can mobilize funding; and the languages and discourses within which development debates can be couched.

These trends - the deepening of both democratization and the neo-liberal economic agenda in developing countries, and the onset of the poverty agenda - have arguably begun to shift the political economy of development funding in ways that create new 
dilemmas for NGOs. Both the desire by donors to have more of international development work focused on large scale poverty reduction, and the advance of national government funding in Asia, Latin America and Africa, have reinforced a shift back towards the state. There is less funding for NGO programme development and innovation - and more for the management and administration of state programmes. In some cases, there is competition from the private sector for these funds although there is some awareness of mixed results (eg. the experiences with subsidised housing and shelter improvements in Latin America: Ferguson 2002 and Stein 2005). ${ }^{12}$ Many argue that voluntary sector organizations in North and South have suffered from greater emphasis on cost recovery, charging for services, professionalised staff relationships, the dominance of competition and the rise of tenders (Wallace 1997, Townsend and Townsend 2004, Bebbington 2005). Under wider shifts towards solving social problems through 'public-private partnerships', there has been an increasing tendency to link commercial enterprise (profit, efficiency) and not-for-profits (community mobilisation) (Fowler 2004: 19). While this blurring between civil and market logics holds the potential to inject a stronger sense of the social within the corporate logic of the private sector and to provide greater resources for social programmes, there is perhaps greater potential for the reverse to predominate, such that the 'pro-market diversification of (NGO) relationships...is an erosion of their potential as agents of systemic social and political change' (Fowler 2004: 1).

A further trend in funding has been the switch to direct funding of NGOs in the South. While larger South-based NGOs ${ }^{13}$ have been successful in raising funds from these 
sources, smaller NGOs have less capacity to deal with the bureaucracy of bilateral agencies, suggesting that over time there will be more concentration in both the Northern and Southern NGO sector. At the same time, new conditionalities on bilateral funds offered to Northern NGOs have placed additional constraints even on these more traditional sources of money. Some Southern NGOs complain that Northern NGOs are becoming more like bilateral agencies than nongovernmental partners. The same is said by emerging NGOs in the South when they are funded through the capacity development programmes of big Southern NGOs. NGOs have struggled to adapt to this funding climate. Many spend considerable time chasing money that is not very useful to them. NGOs need considerable financial skills to manipulate this situation to their advantage, pursue an alternative agenda and still to be seen as competent. Meanwhile there is little interest in funding more innovative activities, and certainly not those oriented toward systemic alternatives and challenging hegemonic ideas. The changing donor priorities are already evident in South Africa where the urban sector NGOs have seen significant closure and contraction - despite rising inequality and a growing housing backlog.

The third trend marking the most recent years has been the rise of the security agenda Western security not human or livelihood security (Duffield 2001, Fowler 2004, Lister 2004). NGOs have long operated in the context of global conflicts not only as humanitarian actors but also as active promoters of system change, often in ways related to the political and social justice movements onto which the NGOs mapped: think, for instance, of the conflicts in Central America. However, the issues raised by conflict have changed significantly since Edwards et al.'s (1999) comments concerning the roles that 
NGOs can and should play within conflict zones. In particular the shift from conflicts organized very broadly around left/right splits to conflicts that include those framed by key actors in terms of Islamic/non Islamic divisions leave some NGOs in far more ideologically complex positions in which their existence as western organizations funded by powers viewed by others as hostile to Islam can complicate their relationships with groups and movements with whom they might usually have presumed to identify. At least in cold war Central America NGOs knew that their enemies really were their enemies. Today - to go back to our introduction - precisely because NGOs are part of little $\mathrm{d}$, and are perceived to be part of it, they can end up being more alone and apparently more politically if not ethically compromised.

The security agenda has never been entirely separable from either little d or big D. In terms of the former, contemporary violence and conflicts have emerged in direct relation to uneven unfoldings of modernity, involving contested processes of state formation and the tensions wrought by social change (e.g. Bates 2001). The links between little d and the current threat of terror from some Islamic movements has also been made by those observers who stress the importance of linking such movements to this specific phase of modernity (Watts, 2003). Meanwhile, the big D aid project has frequently been subsumed within the wider geopolitics of western foreign policy, most notably within the Cold War period, with NGOs hardly exempt from the dilemmas that this threw up. Even prior to this, the soon to be World Bank President Robert McNamara had stated in 1966 that 'In a modernizing society security means development...Security is development, and without development there can be no security' (quoted in Kraske 1996). In several senses, then, 
the current 'war on terror' has not fundamentally re-shaped the problematic of how Development and security are linked. Rather, it constitutes a new phase of historical efforts to re-engineer modernity in the periphery.

But we should not push this argument too far: some differences are of course apparent, although these differ according to geographical context, as illustrated by the wellpublicized argument between the US and UK branches of Save the Children concerning the extent to which it was permissible for SCF to criticize the bombing of Iraq (Maguire, 2003). Given USAID's insistence that its recipients commit to ensuring that no USAID money is associated with potential terror groups, Fowler (2004: 16) points out that those NGOs that accept funding from USAID effectively become agents of the US government, responsible for the compliance of their partners with US foreign policy. While again this was probably always the case - and is in large measure why some US NGOs consistently refused USAID support - the significance is now particularly pressing. Indeed, even those US NGOs categorically refusing government support must follow tax and legal guidelines that require them to be sure they are not supporting groups antithetical to particular elements of US foreign policy.

What is perhaps most relevant here is the different positioning of Northern NGOs on this issue. Where some have either refused to work in countries such as Iraq and Afghanistan, or to accept bilateral funding from aggressor states to work therein, others have either applied a peg to their nose and followed what they perceive to be their mission despite opposing the war on terror, or taken the view that their humanitarian aims are compatible 
with the new imperialism (Lister 2004: 8). This range of positioning reveals not only the extent to which the political economy of aid, and NGO dependency on official flows, limits their room for manoeuvre, but also the immense differences among NGOs in how they understand and approach the notion of pursuing 'alternatives.' For those unable or unwilling to extract themselves from the vagaries of big $\mathrm{D}$, the character of the latest nexus between security and development means that the result is complicity in a wider form of little $d$ that has little discernible link to a project of equity, social justice and political inclusion.

In the very broadest sense these trends fall under the rubric of modern neo-liberal globalization. While economies and geo-politics were always global in reach and exercise, some authors suggest that in more recent times the tendency towards globalizing governance of both national and everyday processes, and even of life and death, has become more marked - and that NGOs are both part of and complicit in these practices (Duffield, 2001; Ferguson and Gupta, 2002). Simultaneously, these trends present NGOs with new challenges and opportunities. One manifestation of this is the increased weight given to advocacy by some NGOs. This reflects a recognition that in the face of such powerful forces, local level project interventions cannot constitute alternatives of any significance or durability, and that changes to policy and wider norms are required if viable alternatives are to be built. Such NGO advocacy has often been transnational in character, with pressure placed at various points along commodity, policy and other chains - from the point of production, up to the arenas in which loans are agreed and shareholders meet annually. ${ }^{14}$ Although an example of how NGOs read and 
engage with the globalised character of both big $\mathrm{D}$ and little $\mathrm{d}$ development, there remains a risk here that the local and the tangible will become lost: as a Ugandan NGO leader warned when ActionAid shifted to a policy focus '.. and when we ask villagers what ActionAid does they will tell us 'oh, they just talk'. Furthermore, the move towards advocacy is bound up with another acute challenge for NGOs, that of representation (Jordan and van Tuijl, 2000). Advocacy presumes representation, but how do NGOs assume such representativeness and legitimate the positions taken in advocacy (Riles, 2001)? This dilemma is perhaps particularly pressing for Northern NGOs, but is also serious for those in the South facing social movements who question the right of NGOs to assume such positions, and occupy such slots in political debate.

\section{On being alternative: reforming interventions, transforming ideas}

In a chapter focused in part on the links between NGOs and ideas in development, Hulme (1994) noted that NGO staff working in the 1970-80s were well-versed in the radical writings of Paulo Freire and Saul Alinsky, both of whom, concerned with hegemony, tried to uncover underlying structures of oppression within the dominant order. ${ }^{15}$ Today, bookshelves in NGO offices are as likely to display sector-specific, less politicised and more technocratic texts (e.g. Fowler 1997 and 2000b), reflecting how the deep changes in both the character of NGOs and the intellectual world around them (Lewis, 2005). Some commentators even suggest that the range of available development alternatives has become circumscribed to a simple dichotomy between the economistic neo-liberalism of the IMF and the UNDP's human development approach (Pieterse 1998). 
This proposed dichotomy is problematic, both in terms of its reading of development alternatives $^{16}$ and of NGO engagements with such alternatives. In particular, it understates the nuanced ways in which some NGOs have tried to elaborate new ways of being an NGO (Edwards and Hulme, 1996; Bebbington, 1997) while also arguing that the business of alternatives, too large and important a task for NGOs alone, must necessarily involve other institutional arenas, particularly the state. ${ }^{17}$ This is so for both significant reformist alternatives, as well as more radical systemic alternatives. Thus, while one of the most noted examples of reformist 'alternative development' success in recent years participatory budgeting in Brazil - involved NGOs, most of the key actors have been leftist political parties, civil society activists, social movements and church-related organisations (Abers, 1998; Cabannes 2004). The history of radical societal change also demonstrates that either developmental states and/or governments in alignment with broad based social movements have led transformative projects (whether towards greater equity, social justice and political inclusion, or towards [neo]liberalization and privatization) far more than have NGOs, think tanks or charities (Tilly, 2004;Clark, 1991, Houtzager 2003, Leftwich 1995). In this final section we therefore consider the types of relationships through which NGOs might reclaim a role in promoting both reformist and radical alternatives.

\section{NGO pathways to reforming 'D'evelopment}


The participatory budgeting example illustrates the argument that one NGO route to large scale alternatives is through influencing the interventions of other actors, both through direct engagement and by providing alternative models of intervention. The work of BRAC on primary education in Bangladesh constitutes another example of NGOs offering genuine alternatives to the state in terms of public service provision (Nath et al 1999). The Law of Popular Participation in Bolivia also reflects a policy adoption of prior NGO led experiments in participatory development planning (Kohl, 2003). While such examples are relatively scarce, casting doubt both on NGOs ability to innovate as well as on many states' willingness to allow significant reforms in the policy process (e.g. Fowler 2000b), they point to ways in which NGOs have been embedded in larger social processes that ultimately take form broad based policy and political change. Some NGOs have been the think tanks or laboratories of broader political movements - a form of ministries in waiting - whose products scale up (at least partially) once the movements ascend to formal government power.

Another route to reform is through working within mass movements with the understanding that politics responds to the electoral effects of mobilization rather than to any professional reform competence. Indeed, there appears to be growing interest in alliances between mass movements and NGOs that can strategically influence candidates, politicians, their professionals and bureaucrats (e.g. Shack/Slum Dwellers International). In these instances, NGOs tend to work with movements to secure their own spaces, rather than to occupy spaces opened by the state - a process slightly less prone to clientelism (Appadurai 2001, Delamaza et al, 2006). 
Other alliances engage actors beyond social movements. The basis of many NGOs in class, religious and party political institutions and networks that do not derive primarily in the popular sectors further fosters such a tendency. UK NGOs, for instance, have become increasingly aware of their need to reach out to new constituencies who do not necessarily equate NGO activity with the broader and fundamentally political goals of achieving global social justice (Lister 2004). At a different extreme, in Peru, NGOs that have historically had a very strong position vis-à-vis extractive industries have also begun to open links with both the mining sector as well as political parties with a view to finding a dialogical pathway to reform. Who reforms who in these processes remains far from clear.

\section{$N G O s$, hegemony and alternative 'd'evelopments}

If pushing to reform the 'D'evelopment interventions of other actors is one path towards to alternatives, another revolves around strategies to transform the foundational ideas and social relations underlying the contemporary social order. The role that NGOs played in promoting democratisation during the 1980s and 1990s as part of broader civil society movements constituted an effort to create a genuine alternative form of politics. ${ }^{18}$ Where NGOs engage with and support social movements and popular organisations that are demanding the extension of citizenship status and rights to marginal peoples - and doing so in ways that are broadly democratic as opposed to exclusive efforts to secure privileges - they can claim to be engaging with underlying processes of citizenship formation (Appadurai, 2001; Fox 1994; Hickey 2002). Initiatives such as the 'Make 
Poverty History' campaign likewise seem to reflect NGO response to the call that they cease trying to solve poverty and instead make the point that poverty can be solved (Pearce 1997), and reflects a strategy that engages alternatives at the level of foundational ideas rather than projects. Such moves, however, require an acute sense of timing. Arguably the best NGO interventions, such as those referenced above, come from recognising key moments within underlying development processes and framing interventions in supportive relation to such progressive moves. Getting timing wrong can at best fulfill the prophecy of the Ugandan activist worrying about ActionAid's policy focus, and at worst risk disarticulation, persecution and death of broader movements pushing for more foundational change. All too often it seems unclear whether NGOs - or many academics within development - are capable of recognizing, reading and engaging constructively with underlying processes of development. While the South African NGO activist Allan Kaplan lists 'development knowledge' as the foremost NGO organizational capacity, he also notes that this capacity is rarely well developed (Kaplan 2001).

\section{Conclusion: New metaphors for NGOs}

The implication of much of the foregoing is that how far, and in what way, NGOs are able to contribute to the reclaiming of development as an alternative project will depend very much on their ability to build relationships with progressive actors operating in the state, in political parties, in social movements and in other domains. This echoes Fowler's suggestion that 'the coming years are likely to see a greater focus on the 
complicated interface between civil society and political society, such as political parties and elective and legislative processes'(2004: 7), and marks a somewhat belated realization within the NGO literature that more complex engagements with politics are required (Houtzager 2003).

If an NGO's management of relationships therefore becomes a central development challenge rather than a management challenge (Lewis, 2001), what might some of these relationships be and what do they imply for ways of being an NGO? In the spirit of finding memorable analogies, we close with a reflection on two such modes: 'the NGO as jelly' and 'the NGO as microchip.' Both involve relinquishing to a significant extent the idea of NGOs being innovative think tanks or pilot projects with brilliant insights capable of articulating alternatives that are so convincing that politicians lay down the red carpet and capitalism abandons the profit motive. Both involve groups that accept they are in a long-term battle over hegemonic ideas against very powerful forces that will reorganize to ensure continued elite control of resources.

The NGO as jelly - In this model the NGO accepts it has little power except that which is generated by being a convenor. The NGO builds alliances with more powerful groups, social movements, political parties, rich donors etc. and they seek to respond to opportunities that emerge within these relationships. They put emphasis on a process that draws in pro-poor individuals and groups, and they are essentially responsive to that process. They have to be a jelly because they are dealing with powerful entities who don't hesitate to contest the process; and they are realistic enough to recognize that they 
have little power within the development process so by necessity they fit into gaps. The NGO gets pushed and pulled but its gelatinous nature - based in large measure in its strong sense that its role is above all else to convene - helps it hold something together. This gelatinous nature draws on what the context offers; for Southern NGOs, it often involves links (family, education, religious) between social elites that cross market, state and civil society divides. For both North and South, it may draw on international connections (with associations of informational and financial resources). In both cases, NGOs' role may depend in part on an anti-poor prejudice that makes the state and other elites reluctant to deal directly with poor citizens, even when they wish to make such alliances. Equally, their cross-sectoral relationships may help to encourage social movements and sometimes the corporate sector and the state to share ideas and begin a negotiation process. In such a model, NGOs make a significant contribution in terms of supporting a governance model that is more inclusive than traditional approaches to state consultation processes. The emphasis on process can, though, be difficult, and in some cases reducing their own visibility can be detrimental as it can give space to other actors do wish to claim profile.

The NGO as microchip - The second model is one in which NGOs seek to be more proactive around the content that is considered within the engagement. They are still concerned with process but the NGO is less willing to relinquish leadership to others than in the jelly model. Their relative lack of power means that they still have to be subtle and persuasive, slipping their ideas into discourses as they are reworked. They may seek to convince a more powerful actor, such as a state minister or agency professional, of the 
merit in their approaches. Some of these NGOs find that their convening legitimacy depends on their playing a microchip rather than a jelly role. In this case, it is their intellectual contribution that enables them to bring actors together with some legitimacy. NGOs can add real insight to local grassroots and political strategies by broadening horizons and helping people learn and see things differently. At other times, their capacity to overview other experiences means that they define the boundaries within which alternatives can be discussed. It is for this reason that research-based NGOs in particular are able to take on a convening role.

Both these kinds of NGOs are small (or may be a component of a bigger NGO), both essentially intermediate. Sometimes they need to implement - in the same sense that the best advocacy work done by NGOs often draws on their operational experience - but they are not essentially doers (although they may work with other NGOs who are). The more successful alternative models avoid getting drawn into operational roles because these increase administrative burdens for NGOs that divert them from thinking strategically. They therefore employ limited numbers of high-quality versatile people and invest in their skills and capacities. In each case being an NGO worker becomes a vocation rather than a job, and the goal is that the networks built will be enduring. These networks accompany political changes and exploit opportunities with wisdom rather than opportunism. $^{19}$

What we have sought to do here is to suggest that NGOs can still contribute significantly to development alternatives, and that this requires a direct and critical engagement with 
development as a long-term process of social change, driven primarily by particular and increasingly globalised forms of capitalism, (re)shaped by states at different stages of formation, endlessly contested over within civil society, and with specific outcomes in terms of citizenship and social justice for people and societies. Of course, in the end the key issue remains the extent to which the political economy of NGOs will persuade them of the need to reclaim a role for themselves as agents of transformative approaches to development. The extent to which NGOs have managed to maintain a significant slice of the overall cake of development finance suggests that many are a long way from feeling the pinch.

\section{References}

Abers, R 1998 'Learning democratic practice: distributing government resources through popular participation in Porto Alegre' in Douglass, M and J. Friedmann (eds.) Cities for Citizens: Planning and the Rise of Civil Society in a Global Age, John Wiley and Sons, Chichester.

Aldaba, F., Antezana, P. Valderrama, M. and Fowler, A. 2000 'NGO strategies beyond aid: perspectives from Central and South America and the Philippines' Third World Quarterly 21(4): 669-683

Alvarez, S., Dagnino, E. and Escobar, A. (eds) 1998: Culture of politics/ politics of cultures. Re-visioning Latin American social movements. Boulder. Westview.

Andrews, K. 2001 'Social movements and policy implementation: The Mississippi civil rights movement and the war on poverty, 1965-1971' American Sociological Review 66(1): 71-95

Appadurai, A. 2001. 'Deep democracy: urban governmentability and the horizon of politics' Environment and Urbanization 13(2): 23-44

Ballard, R., Habib, A., Valodia, I and Zuern, 2005 'Globalization, Marginalization and Contemporary Social Movements in South Africa' African Affairs 104(417): 615634 
Bates, R. 2001: Prosperity and Violence: The Political Economy of Development. New York/London: Norton and Company.

Bebbington, A.J. 2006: 'Social capital and development studies II: can Bourdieu travel to policy?', Progress in Development Studies, forthcoming.

Bebbingon A J 2005, ' Donor-NGO relations and representations of livelihood in nongovernmental aid chains' World Development, 33(6), 937-950.

Bebbington A J 2004 'NGOs and uneven development: geographies of development intervention', Progress in Human Geography, 28(6): 725-745.

Bebbington A J 2003 Global Networks and Local Developments: Agendas for Development Geography Tijdschrift voor Economische en Sociale Geografie 94(3): 297-309

Bebbington, A. 1997: 'New states, new NGOs? Crisis and transition among Andean rural development' NGOs. World Development 25, 1755-1765

Bebbington, A. and Hickey, S. 2006 'NGOs and civil society' in D.A. Clark (ed.) The Elgar Companion to Development Studies. Cheltenham. Edward Elgar

Bratton, M. 1989. 'The Politics of Government-NGO Relations in Africa', World Development, Vol.17, No.4, 569-587.

Brown, D. (2004). Participation in Poverty Reduction Strategies: Democracy Strengthened or Democracy Undermined? In S. Hickey and G. Mohan (eds.) From Tyranny to Transformation? New Approaches to Participation. London: Zed Books.

Burwaoy, M. 2003 'For a sociological Marxism: the complementary convergence of Antonio Gramsci and Karl Polanyi', Politics and Society, Vol.31, No.2, 193-261.

Cabannes, Y 2004 'Participatory budgeting: a significant contribution to participatory democracy' Environment and Urbanization 16(1): 27-46

Chapin, Mac 2004 A Challenge to Conservationists World Watch Magazine: November/ December 2004

Charnovitz, S. (1997) 'Two centuries of participation: NGOs and international governance' Michigan Journal of International Law, 18(2): 183-286

Clark, J. 1991: Democratizing development. The role of voluntary organizations. London: Earthscan. 
Clarke, G. 1998. The Politics of NGOs in South East Asia: Participation and Protest in the Philippines. London: Routledge.

Connolly, P. (2004) 'The Mexican National Popular Housing Fund' in D. Mitlin and D. Satterthwaite (eds.) Empowering Squatter Citizen, Earthscan, London, pages 82111.

Cooke, W. and Kothari, U. (eds.) 2001 Participation: the New Tyranny? London. Zed Books.

Cowen, M. and R. Shenton (1998) 'Agrarian doctrines of development: Part 1', Journal of Peasant Studies, 25: 49-76.

Cowen, M. and R. Shenton (1996) Doctrines of development, London. Routledge.

Delamaza, G., Villar, R. and Bebbington, A., 2006 Client Citizens/Agent Citizens: Grassroots Development and Public Spaces for Civic Engagement in Latin America's Localities. Arlington. InterAmerican Foundation

Drabek, A.G. 1987: Development Alternatives: the challenge of NGOs. World Development Volume 15 (supplement), Autumn 1987.

Duffield, M. 2001. Global Governance and the New Wars: The Merger of Development and Security. London: Zed Books (3rd Edition 2005).

Edwards, M. 1999. Future Positive: International Co-operation in the 21st Century. Earthscan.

Edwards, M. and Hulme, D. 1996 'Too close for comfort: NGOs, the state and donors.' World Development vol 24 No 6 pp 961-973

Edwards, M. and D. Hulme. (eds.) 1995. NGOs: Performance and Accountability: Beyond the Magic Bullet. (London: Earthscan). Reprinted 1996.

Edwards, M. and D. Hulme. (eds.) 1992. Making a Difference? NGOs and Development in a Changing World. (London: Earthscan/Save the Children).

Edwards, M, D. Hulme, and T. Wallace. (1999) 'NGOs in a global future', Public Administration \& Development, Vol.19, 117-136.

Escobar, A. 2001 Culture sits in places: reflections on globalization and subaltern strategies of localization Political Geography 20, 139-174

Escobar, A. 1995 Encountering development: The making and unmaking of the Third World, Princeton: Princeton University Press. 
Ferguson J and Gupta A 2002 Spatializing states: towards an ethnography of neoliberal governmentality American Ethnologist 29, 4 981-1002

Ferguson, B (2002) 'A housing paradigm and new programmes for development countries: the Latin America case' in UN-Habitat, Financing Adequate Shelter for All: Addressing the Housing Finance Problem in Development Countries, UNHabitat, pages 165-170.

Fisher, J. 1998 Nongovernments. NGOs and the political development of the Third World. West Hartford: Kumarian.

Fisher, J. 1993 The Road from Rio: Sustainable Development and Nongovernmental Movement in the Third World, New York: Praeger

Fowler, A. 2004. 'Aid Architecture and counter-terrorism: perspectives on NGO Futures', INTRAC OPS 45. Oxford: INTRAC.

Fowler, A. 2000a. The Virtuous Spiral: a guide to sustainability for NGOs in international development. Earthscan.

Fowler, A. 2000b. 'NGO Futures: beyond aid: NGDO values and the fourth position', Third World Quarterly, Vol.21, No.4, 589-603.

Fowler, A. 1997. Striking a balance: a guide to enhancing the effectiveness of nongovernmental organisations in international development. (London: Earthscan).

Fowler, A. 1993. 'Non-governmental Organisations as Agents of Democratization: An African Perspective'. Journal of International Development, Vol.5, No.3, 325339.

Fox, J. 1994. 'The Difficult Transition from Clientelism to Citizenship. Lessons from Mexico', World Politics, Vol.46, 151-184.

Gariyo, Z. 1995. 'NGOs in East Africa: a View From Below'. In Edwards and Hulme, op cit., $131-139$.

Gary, I. 1996. 'Confrontation, Co-operation or Co-optation: NGOs and the Ghanaian State during Structural Adjustment', Review of African Political Economy, No. $68,149-168$

Geisler, G. (2000). 'Parliament is another terrain of struggle': women, men and politics in South Africa. Journal of Modern African Studies, 38(4): 605-630.

Goetz, A-M. (2003). The problem with patronage: constraints on women's political effectiveness in Uganda. In A. M. Goetz and S. Hassim (eds.) No shortcuts to power: African women in politics and policy-making. London: Zed. 110-139. 
Gore, C. 2000. 'The Rise and Fall of the Washington Consensus as a Paradigm for Developing Countries', World Development, 28(5), 789-804.

Green, M. and Hulme, D. 2005 'From Correlates and Characteristics to Causes: Thinking About Poverty from a Chronic Poverty Perspective', World Development 33 (6): 867-879

Groves, L. and Hinton, R. (2004) Inclusive Aid: Changing Power and Relationships in International Development. London: Earthscan.

Hart, G. 2001 Development critiques in the 1990s: culs de sac and promising paths. Progress in Human Geography 25, 649-658

Hashemi, S. 1995. 'NGO Accountability in Bangladesh: Beneficiaries, Donors and the State'. In Edwards and Hulme, op cit., 103-110.

Hearn, J. 2001. 'The Uses and Abuses of Civil Society in Africa', Review of African Political Economy, No.87, 43-53.

Hickey, S. 2002. 'Transnational NGDOS and participatory forms of rights-based development: converging with the local politics of citizenship in Cameroon', Journal of International Development, Vol.4, No.6, 841-857.

Hickey, S. and S. Bracking 2005. 'Exploring the politics of poverty reduction: from representation to a politics of justice?', World Development, Vol.33, No.6, 851865.

Hickey, S. and Mohan, G. 2005. 'Relocating participation within a radical politics of development', Development and Change, Vol.33, No.2, 237-262.

Hirschman, A. 1984 Getting ahead collectively. Pergamon Press.

Howell, J. and Pearce, J. 2001: Civil society and development: a critical exploration. Boulder: Lynne Reinner.

Houtzager, P. (2003). Introduction: from polycentrism to the polity'. In P. Houtzager and M. Moore (eds.) Changing Paths: International Development and the New Politics of Inclusion. Michigan: University of Michigan Press. 1-31.

Hulme, D. 1994. 'Social development research and the third sector: NGOS as users and subjects of social inquiry'. In D. Booth (ed.) Rethinking Social Development: theory, research and practice. Harlow: Longman. Pp. 251-275.

Hyden, G. 1997 ' Civil Society, Social Capital, and Development: Dissection of a Complex Discourse.' Studies in Comparative International Development 32: 3-30 
Jordan, L. and van Tuijl, P. 2000: Political responsibility in transnational NGO advocacy World Development 28(12): 2051-2065.

Kaplan, A. (2001) 'Capacity building: shifting the paradigms in practice'. In D. Eade (ed.) Debating Development. OXFAM.

Kohl, B. 2003 'Non Governmental Organizations and Decentralization in Bolivia,' Environment and Planning C: Governance and Planning, 21(2): 317-331

Kraske, J. (1996) Bankers with a Mission: The Presidents of the World Bank, 1946-1991. Oxford University Press.

Lane, J. 1995. 'Non-governmental organisations and participatory development: the concept in theory versus the concept in practice'. In Nelson, N. and S. Wright (eds.) Power and Participatory Development: Theory and Practice. (London: Intermediate Technology Publications). 1996 Reprint, pp. 181-191.

Lavalle, A.G., A. Acharya and P.P. Houtzager (2005) 'Beyond comparative anecdotalism: lessons on civil society and participation from São Paulo, Brazil', World Development, 33(6): 951-964.

Leftwich, A. (1995) 'Bringing politics back in: Towards a model of the developmental state', The Journal of Development Studies, 31/3.

Lehmann, A.D. 1990 Democracy and development in Latin America. Economics, politics and religion in the postwar period. Cambridge. Polity Press.

Lewis, D. 2005 'Individuals, organizations and public action: trajectories of the 'nongovernmental' in development studies.' In U.Kothari (ed.) A Radical History of Development. London. Zed. Pp. 200-221

Lewis, D. 2002 'Civil society in African contexts: reflections on the 'usefulness' of a concept', Development and Change, 33(4): 569-86

Lewis, D. 2001 The Management of Nongovernmental Organizations. London. Routledge.

Lewis, D and T. Wallace. (eds.) 2000. New Roles and Relevance: Development NGOs and the Challenge of Change. (West Hartford, Conn: Kumarian Press).

Lister, S. 2004. The future of international NGOs: new challenges in a changing world order. Paper for BOND Futures programme. http://www.bond.org.uk/futures/

MacDonald, L. 1996 'Globalizing civil society: interpreting NGOs in Central America' Millenium: Journal of International Studies 23(2):267-285 
Maguire, K. (2003) 'How British charity was silenced on Iraq', The Guardian, 28 November.

Mamdani, M. 1993. 'Social Movements and Democracy in Africa', in P. Wignaraja (ed.), New Social Movements in the South: Empowering the People. (UK: Zed). 101118.

Marcussen, H. S. 1996. 'NGOs, the State and Civil Society', Review of African Political Economy, No.69, 405-423.

McAdam, D. 1988 Freedom summer. New York. Oxford University Press.

McCarthy, J. and Zald, M. 1977 Resource mobilization and social movements American Journal of Sociology 82(6): 1212-1241

Mercer, C. 2002. 'NGOs, civil society and democratization: a critical review of the literature', Progress in Development Studies, Vol.2, No.1, 5-22.

Michael, S. 2004. Undermining Development: The absence of power among local NGOs in Africa. Oxford: James Currey.

Midgeley, J. 2003. 'Social development: the intellectual heritage' Journal of International Development, Vol.5, No.7, 831-844.

Mitlin, D and D. Satterthwaite (2004) Empowering Squatter Citizen: Local government, Civil Society and Urban Poverty Reduction, Earthscan Publications Ltd, London.

Nath, S.R., K. Sylva, J. Grimes. 1999. 'Raising basic education levels in rural Bangladesh: The impact of a non-formal education programme', International Review of Education, 45(1): 5-26

Ndegwa, S. 1996. The Two Faces of Civil Society in Africa: NGOs and Politics in Africa. West Hartford, Conn: Kumarian Press.

Nerfin, M. 1977. (ed.) Another Development: approaches and strategies. (Uppsala: Dag Hammarskjold Foundation).

Organization for Economic Cooperation and Development (OECD). 1988. Voluntary aid for development: the role of non-governmental organizations. Paris: Organization for Economic Cooperation and Development.

Patel, S. and D. Mitlin. (2002) 'Sharing Experiences and Changing Lives', Community Development Journal, 37(2): 125-36. 
Pearce, J. 1997 'Between cooption and irrelevance? Latin American NGOs in the 1990s' pp. 257-274 in D. Hulme and M. Edwards (1997) Too close for comfort? NGOs, states and donors. London. St. Martins.

Peck, J. 2004 'Geography and public policy: constructions of neoliberalism.' Progress in Human Geography, 28(3): 392-405.

Pieterse, J.N. 1998. 'My Paradigm of Yours? Alternative Development, Postdevelopment, Reflexive Development', Development and Change, Vol.29, 343373.

Portes, Alejandro and Patricia Landolt. 1996. 'The Downside of Social Capital,' The American Prospect, 26: 18-22.

Putzel, J. 1997. 'Accounting for the 'dark side' of social capital: reading Robert Putnam on democracy', Journal of International Development, 9(7): 939-949.

Riddell, R.C and M. Robinson, et al. 1995. Non-Governmental Organizations and Rural Poverty Alleviation. (London: ODI/Oxford: Clarendon Press).

Riles, A. 2001 The network inside out. Ann Arbor. University of Michigan Press.

Robinson, M. 1997 'Privatising the voluntary sector: NGOs as public service contractors?’ pp. 59-78 in Hulme and Edwards (1997)

Robinson, M. 1995. 'Strengthening civil society in Africa: the role of foreign political aid', IDS Bulletin, Vol.26, No.2, 70-80.

Slater, D. (ed.) 1985 New social movements and the state in Latin America. Amsterdam. Cedla.

Stein, A. with L. Castillo (2005) 'Innovative financing for low-income housing improvement: lessons from programmes in Central America,' Environment and Urbanization 17(1): 47-66

Stewart, S. 1997. 'Happy Ever After in the Marketplace: Non-government Organisations and Uncivil Society'. Review of African Political Economy, No.71, 11-34.

Stone, D. 2000 'Non-governmental policy transfer: the strategies of independent policy institutes' Governance: an international journal of policy and administration 13(1): 45-62

Tandon, R. 2001. 'Riding high or nosediving: development NGOs in the new millenium'. In D. Eade and E. Ligteringen (eds) Debating Development. Oxford: OXFAM. 44-59. 
Tandon, R. 1991. 'Foreign NGOs, Uses and Abuses: An African Perspective', IFDA Dossier, 81, 67-78.

Tilly, C. 2004 Contention and democracy in Europe: 1650-2000. Cambridge. Cambridge University Press.

Townsend, J. 1999. 'Are Non-governmental Organizations Working in Development a Transnational Community?’, Journal of International Development, 11, 613-623.

Townsend, J., Porter, G. and Mawdesley, E. 2004 'Creating Spaces of Resistance: Development NGOs and their Clients in Ghana, India and Mexico' Antipode 36 (5): 871-889

Townsend, J., Porter, G. and Mawdesley, E. 2002: The role of the transnational community of development non-governmental organizations: governance or poverty reduction? Journal of International Development 14, 829-839.

Townsend, J.G. and A.R. Townsend, 2004 'Accountability, motivation and practice: NGOs North and South' Social and Cultural Geography 5(2): 271-284

Uphoff, N. 1995. 'Why NGOs are Not a Third Sector: a Sectoral Analysis with Some Thoughts on Accountability, Sustainability and Accountability',. In Edward and Hulme, op cit., 17-30.

van Rooy, A. 2000. 'Good news! You may be out of a job: reflections on the past and future 50 years for Northern NGOs', Development in Practice, Vol. 10, Nos. 3-4, 300-317.

Wallace, T., Crowther, S. and Shepherd, A. 1997. Standardising Development: Influences on UK NGOs' Policies and Procedures. Oxford: World View Publishing.

Wallace, T. 1997. 'New Development Agendas: changes in UK NGO policies and procedures' Review of African Political Economy 71: 35-55

Watts, M. 2003 'Development and Governmentality.' Singapore Journal of Tropical Geography 24 (1): 6-34

Watts, M. 2001 '1968 and all that.....' Progress in Human Geography, 25(2): 157-188.

WorldWatch, 2005 'Readers' Responses to 'A Challenge to Conservationists' World Watch Magazine: January/ February 2005 


\section{Notes}

${ }^{1}$ A longer version of this paper was prepared as a background paper for the GPRG and Ford Foundation funded conference, 'Reclaiming Development: Assessing the Contribution of NGOs to Development Alternatives Conference', held at Manchester, 27-29 June 2005. We are grateful to comments received on the paper, in particular from Pim Verhallen, David Hulme, Giles Mohan and David Lewis. The work has been made possible by a grant from the ESRC to the Global Poverty Research Group (GPRG) at the Universities of Manchester and Oxford (grant no. M571255001).

${ }^{2}$ The risk is that the paper repeats the limitations of the more general normative turn that Lewis (2005) identifies as a source of much analytical weakness in writing about NGOs and development. We would argue, though, that all development studies is normative, and that what matters more is making one's normative position clear, and engaging it with a theoretical framework in such a way that avoids a normative commitment becoming a romanticized argument.

${ }^{3}$ Polanyi actually talked of 'active society.'

${ }^{4}$ There is a clear relation here to the social capital literature in which social capital has been deemed a source of 'good' by many authors, downplaying its dark and down-sides (Putzel, 1997; Portes and Landolt, 1996; Bebbington, 2006).

${ }^{5}$ For this problem in the environmental NGO sector, see Chapin (2004), WorldWatch (2005).

${ }^{6}$ This omits the deeper history to which Lewis refers. In addition, we do not specifically discuss the type of relief-oriented NGO that has historically emerged throughout each of our four stages, in direct relation to specific emergencies, as with the Sahelian drought of the 1970s, Hurricane Mitch or the earthquakes in Gujarat.

${ }^{7}$ Think for instance of the Gates Foundation, the Gordon Moore Foundation and the Soros Foundation.

${ }^{8}$ As just two examples from the urban sector, consider the Orangi Pilot Project (OPP) and the Centro Operacional de Vivienda y Poblamiento AC (COPEVI). OPP works in Karachi (Pakistan) and seeks to improve levels of infrastructure and services in low-income settlements. Over time their strategy has changed, but during the 1980s they very deliberately set out to demonstrate alternatives to the state. COPEVI is a Mexican NGO whose ideas for improving low-income urban settlements were later taken up in the government programme FONHAPO (Connolly 2004).

${ }^{9}$ As illustrated by Ndegwa (1996) in Kenya, NGOs tended to concentrate on social service provision rather than more overtly political strategies to secure pro-poor social change.

${ }^{10}$ An argument that only helps explain so much - there are several experiences of adjustment under authoritarianism - e.g. Chile.

${ }^{11}$ Though note our earlier comments about difficulties in defining neo-liberalism in the singular.

12 Examples here include those housing programmes that offer a subsidy and a role for intermediaries in using state finance for housing improvements and new build.

${ }^{13}$ Some of whom are Northern NGOs based in the South.

${ }^{14}$ See for instance advocacy strategies around mining by Oxfam America.

${ }^{15}$ By 2000 , he found that none of the 40 plus participants on his NGO teaching module had heard of either Freire or Alinsky.

${ }^{16}$ Pieterse positioned the World Bank as closer to the IMF on this continuum, but as moving towards UNDP, an adroit reading of the Bank's then incipient shift away from the Washington consensus in the aftermath of the Asian Crisis. However, one of several flaws with this approach is that it positioned social development as a genuine alternative to the mainstream neo-liberal 
orthodoxy. However, as Midgely's (2003) historical review of social development suggests, social development (as commonly conceived in the North) shares many of the same presuppositions as both the neo-liberal agenda (e.g. individualism) and the interventionist development agenda (e.g. the belief in planning and social engineering), and so does little to challenge the basic tenets of mainstream agenda. A more worthy opponent here might be the neo-structuralism and developmental statism of the ECLA/South Asian school, which can claim the most significant development transformations in the global south over the past thirty years (Gore 2000). Importantly, this latter approach would seem to have little role for NGOs.

${ }^{17}$ See Mitlin and Satterthwaite (2004) for some recent examples of such collaboration in addressing urban poverty.

${ }^{18}$ As did the role played by quasi-NGO social movement organizations within the US civil rights movement in the 1960s (McAdam, 1988; Andrews, 2001).

${ }^{19}$ Scaling up and changing the world do not go together and may at times even enter into conflict with each other. 'Changing the world' roles cannot easily be scaled up unless the intervention is very specific and not contested - all that happens is the commitment, wisdom and momentum are lost. But processes can be scaled up when the process is based on strong, and appropriate, relationships. In this latter option, the NGO remains small but it spawns other actors and initiatives and then links to them. This model is essential non-centrist. We suspect that the strongest NGOs are in fact, and ironically, those that give up on any effort to control processes. 